
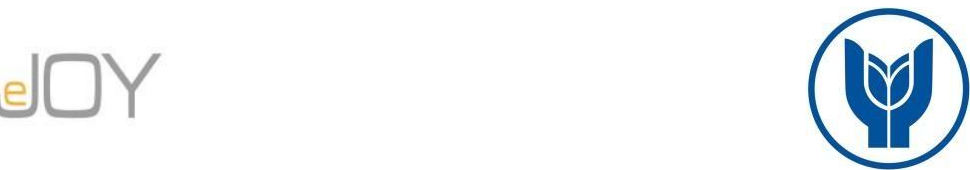

Kurt Yılmaz, B., Güler, M. E., Sürgevil Dalk1lıç, O. / Journal of Yasar University, 2021, 16/62, 960-981

\title{
Sağlık Çalışanlarının Covıd-19 Küresel Salgınına Bakış Açılarının ve Tutumlarının Değerlendirilmesi ${ }^{12}$
}

\section{Evaluation Of Health Workers Perspectives And Attitudes To The Covid- 19 Global Outbreak ${ }^{3}$}

\author{
Benan KURT YILMAZ, Sinop Üniversitesi, Türkiye, bkurt@sinop.edu.tr \\ Orcid No: 0000-0002-1265-7136
}

Mehmet Emre GÜLER, İzmir Kâtip Çelebi Üniversitesi, Türkiye, memre.guler@ikc.edu.tr

Orcid No: 0000-0002-8689-9859

Olca SÜRGEVILL DALKILIÇ, Dokuz Eylül Üniversitesi, Türkiye, olca.surgevil@ deu.edu.tr

Orcid No: 0000-0002-7667-8104

\begin{abstract}
Öz: Dünyayı etkisi altına alan pandemi sırasında ön sırada yer alan sağlık çalışanlarının mesleki bilgi ve becerilerini kullanırken göstermiş oldukları gayretle birlikte duygu ve düşüncelerin dışa vurumu noktasında yaşadıkları da önem arz etmektedir. Bu bağlamda bu araştırmanın amacı, sağlık çalışanlarının COVID-19 salgını hakkındaki görüşleri ile mesleki bilgi ve yeteneklerini sergilerken yaşadıkları duygu ve düşünceleri ortaya koymaktır. Çalışma kapsamında salgının Türkiye'de yoğun bir şekilde yaşandı̆̆ı illerden biri olan İzmir ilinde görev yapan să̆llk personeline ulaşmak amacıyla Çırakoğlu (2011)'nun Türk Psikoloji Dergisi'nde yayınlanmış makalesinde bulunan önermelerden esinlenerek oluşturulan soru formu kullanılmıştır. Amaçlı örneklem metodu ile örnekleme ulaşılmaya çalışllmış; belirlenen 67 katılımcıya COVID-19 salgınına ilişkin duygu ve düşüncelerini ögrenme amaçl soru formu iletilmiştir. Çalışmada elde edilen veriler Maxqda Analytics Pro 2018 Nitel Veri Analizi programı ile analiz edilmiş ve tartışılarak sunulmuştur. Çalışmaya katılan sağlık çalışanlarının COVID-19 salgınına yönelik söylemlerinin en başında virüsün bulaşıcılı̆̆g gelmektedir. Araştırma dönemi itibariyle bulaşı durduracak veya azaltacak bir aşının veya koruyucu tedavinin henüz bulunmamış olması nedeniyle bireylerin virüsün bulaşıcılığından korunmak için izolasyon ve toplu alanlarda mesafeyi korumalarına dikkat çekilmektedir. Katılımcılar; salgının hem toplum hem de sağlık çalışanları üzerinde endişe yarattı̆̆ına, dünyada yapılan çalışmaların virüsle mücadelede konusunda geciktiğine vurgu yapmaktadır. Sağlık çalışanlarının COVID-19 virüsüne ilişkin en çok kullandıkları kelimelerin sembolik temsillerine ilişkin fikir verdiği düşünülmektedir. Virüs ile mücadelede sosyal mesafe, izolasyon, karantina ve sokă̆a çıkma yasă̆ yöntemlerinin öne çıkması ilave olarak sosyal medya paylaşımlarında da bu yöntemlerin görselleştirilerek sunulması virüsün sembolik temsilini de oluşturmaktadır.
\end{abstract}

Anahtar Kelimeler: Küresel Salgın, COVID-19, Să̆lık Çalışanları

JEL Sinıflandırması: I12, C83, D23

Abstract: During the pandemic that has affected the world, it is also important that healthcare professionals, who are at the forefront, experience the expression of their feelings and thoughts, together with the effort they have shown while using their professional knowledge and skills. In this context, the purpose of this research is to reveal the views and feelings, thoughts and experienced by healthcare professionals. To reach healthcare workers, Izmir was chosen as one of the cities that experienced pandemic intensely, and the question form was used, inspired by the propositions found in Çırakoğlu's (2011) paper published in the Turkish Psychology Journal. Purposeful sampling method was used. A questionnaire to learn their feelings and thoughts about the COVID-19 outbreak was sent to 67 participants. The data was analyzed with the Maxqda Analytics Pro 2018 software, and the results were discussed. The contagiousness of the virus is at the top of the discourse of the healthcare professionals participating in the study regarding the COVID-19 outbreak. Due to the lack of a vaccine or preventive treatment to stop or reduce the transmission, as of the research period, attention is drawn

\footnotetext{
${ }^{1}$ Bu çalışmaya, İzmir Katip Çelebi Üniversitesi Sosyal Araştırmalar Etik Kurulu tarafindan 8.5.2020 tarihli 2020-SAE-0026 sayılı yazıyla etik onay verilmiştir. Çalışma ayrıca Sağlık Bakanlığı Bilimsel Araştırma Platformu tarafından da onaylanmıştır.

2 Bu çalışma COVID-19 salgınıyla mücadelede ön sırada yer alan sağlık çalışanlarına ithaf edilmiştir.

${ }^{3}$ This study is dedicated to healthcare professionals who are at the forefront of combating the COVID-19 pandemic.
} 
to the fact that individuals maintain distance in isolation and collective areas in order to avoid the contagiousness of the virus. Participants emphasize that the epidemic causes concern to both the society and healthcare workers, and that the studies conducted in the world are delayed in combating the virus. It is thought to give insight into the symbolic representations of the words most frequently used by healthcare professionals regarding the COVID-19 virus. In addition to the prominence of social distance, isolation, quarantine and curfew methods in the fight against the virus, visualization of these methods in social media sharing also constitutes the symbolic representation of the virus.

Keywords: Pandemic, COVID-19, Healthcare Workers

JEL Classification: I12, C83, D23

\section{Giriş}

Etkileri halen devam eden COVID-19 salgını 21. Yüzyıl için yaşanılan ilk salgın değildir. 2002 yılında ortaya çıkarak 8000'den fazla insanı etkileyen ve 26 farklı ülkede 774 kişinin ölümüne neden olan SARS virüsü salgını yaşanmıştır (Wilder-Smith, 2006). Ancak COVID19 virüsü Çin'in Wuhan kentinde ortaya çıkarak SARS virüsü gibi yerelde kalmayıp 31 Ocak 2020 tarihinde Dünya Sağlık Örgütü’nün de açıklamasında belirttiği gibi küresel bir salgın haline dönüşmüştür (Huang vd., 2020).

Tüm dünyayı etkisi altına alan ve etkilerinin bir süre daha hissedilebileceği öngörülen COVID-19 salgını ülkelerin sağlık sistemlerini zorlamaktadır. Hasta sayısının hızlı yükselişi, mevcut yatak ve sağlık çalışanı kapasitesinin üzerine çıkmış ve bu durum salgının yayılım hızına da olumsuz yönde etki etmiştir. Bu bağlamda salgından korunmak için kullanılan maske, dezenfektan ve koruyucu kıyafet ve malzemelerin bu acil durum içerisinde yetersiz kalması da bir başka hızlandırıcı etken olmuştur. Ülkeler bazında çeşitli tedbirler alınmaya başlanmış ve bu tedbirlerin başında da sokağa çıkma yasakları gelmiş ve belirli yaş grupları için daha sıkı önlemler alınma yoluna gidilmiştir. Bu tedbirlerle birlikte sağlık çalışanları, virüsün yayılım göstermemesi adına virüs ile temas etmiş olabilecek kişileri tespit edebilmek için hastane ve sağlık ocakları dışında da temaslı takibi çalışmalarına başlamıştır. Bu süreçle birlikte sağlık personelinin kurum içi ve dışı çalışma durumları ortaya çıkmıştır. Yoğun çalışma temposunun yanı sıra bu salgının sağlık çalışanı olan her bireyin hayatını da tehdit eder içerikte olması ve bu süreçte sağlık çalışanlarının aileleri ile bulaş riski nedeniyle görüşememesi gibi durumlar gündeme gelmiştir. Bu çalışmada sağlık çalışanlarının küresel salgın ile ilgili görüşleri ve bu salgına bakış açıları ile salgında yaşadıkları karşısında sergiledikleri tutumlar ve deneyimleri araştırılmaktadır.

\section{Literatür İncelemesi}

Sağlık ve hastalık kavramları tüm insanlar için önemli bir konudur. Bireyin günlük yaşamına devam edebilmesi için sağlıklı olması gerekmektedir. Bu nedenle insanlar, sağlıklarını korumak ve olası hastalıklardan mümkün olduğunca az etkilenmek için zaman ve para 
harcamaktadırlar. Bu nedenle sağlıklı olmak, sağlıklı kalabilmek, hastalıklardan mümkün olduğunca kaçınmak ve bir hastalık durumu ile karşılaşıldığında söz konusu durumdan kurtulmak ve tekrar sağlıklı hale gelmek sadece sağlık alanının değil, psikoloji alanının da üzerinde durduğu bir konudur (Narter, 2012: 59). Bu bağlamda Herzlich (1973) bireylerin hem kendileri hem de yakınları ile ilgili sağlık ve hastalık deneyimlerini nasıl karşıladıklarını araştırma konusu yapmıştır. Herzlich (1973) araştırmasında bireylerin hastalık durumlarında söz konusu hastalığa ilişkin edindikleri bilimsel bilgiyi gündelik hayatlarına nasııl taşıdıkları ve nasıl anlamlandırdıklarını sosyal temsiller yoluyla aktarmaya çalışmıştır. Herzlich'e göre, hastalık ve sağlık kavramı sosyal olarak gelişirken söz konusu kavramların içerikleri de sosyal olarak inşa edilmektedir. Diğer bir deyişle hastalığa ilişkin bilimsel bilimsel bilgi deneyimler ile yeniden inşa edilmekte ve diğer bireylere aktarılmaktadır (Joffe, 2002: 560).

Herzlich ve Pierret (1989)'in AIDS hastası bireyler üzerinde yaptıkları çalışma sonucu ortaya koydukları Sosyal Temsil Teorisi'ne göre sağlık ve hastalığın sembolik, duygusal ve sosyal olmak üzere üç boyutu bulunmaktadır. Bu boyutların oluşmasında, güçlenmesinde ve evrilmesinde kitle iletişimin çok önemli bir yeri vardır (Joffe, 2002: 561). Örneğin kitle iletişim araçlarının AIDS hastalığını gündeme taşıyıp aktarmasından önce AIDS hastalarını tanıyan insan sayısı sınırlı iken, bugün AIDS hastalarını ve deneyimlerini kitle iletişim araçlarıyla öğrenen milyonlarca insan bulunmakta ve ilave olarak hastalığa ilişkin bilgi de izleyen kitlenin zihinlerinde yeniden şekillenmektedir (Herzlich ve Pierret 1989: 1236). Söz konusu aktarım ile AIDS hastalığının sembolik boyutu "kırmızı kurdela" iken, sosyal boyutu "ötekiler" olarak marjinalleştirilen bireyler, duygusal boyutu ise "korku" olarak şekillenmektedir. Benzer bir biçimde yaklaşık 20 yıl kadar öncesine kadar kanser hastalarına karşı ayrımcı yaklaşımlar da söz konusu sosyal temsiller yoluyla şekillenmiştir (Stahly, 1988). Aralık 2019'dan itibaren Çin sağlık yetkilileri, etkilenen kişilerde viral pnömoniye neden olan patojeni yeni korona virüsü COVID-19 olarak tanımlamışlardır (Chinazzi vd., 2020). COVID19 salgını ile yaşanan süreçte bireylerde gerçek ve gerçek olmayan korkular nedeniyle oluşan sosyal önyargılar, hem sağlıklı hem de COVID-19 virüsüne yakalan bireylerde; stres ve kayg1 gibi olumsuz duygulara neden olmuştur.

SARS virüsü kadar ölümcül olmasa da, korona virüs enfeksiyonunun daha uzun bir kuluçka süresi olmakla birlikte enfekte olanların çoğu herhangi bir semptom olmadan ya da hafif belirtilerle hastalığı geçirebilmekte ya da taşıyabilmektedirler. Bu durum, hastaların ve hastalığın yayılımının takip edilmesini ve kontrol altına alınmasını zorlaştırmaktadır. Böylelikle COVID-19, SARS'tan daha fazla bulaşıcı etkisi bulunan, küresel ölçekte bir salgın haline gelmektedir (Strielkowski, 2020). Tüm bunlara rağmen, COVID-19'un "kara ölüm 
vebası" olmadığı ve bilimin ilerlemesi sayesinde, sağlık hizmetlerinin yaygın olarak verilebildiği, bulaşıcı hastalıkların nasıl önleneceği ve tedavi edilebileceğinin 14. yüzyıla göre daha iyi olduğu söylense de (Strielkowski, 2020); alınan tedbirlere rağmen yaz mevsiminin sonuna doğru salgın ileri bir seviyeye ulaşmıştır. Öte yandan enfekte olan ve iyileşen kişilerin koronovirüse karşı bağışıklık kazandığı ve bir daha hasta olmayacakları fikri zamanla değişse de, hastalığı geçirenlerin kanlarında bulunan serumlar aracılığıyla üretilebilecek antikorların hastalığı yenmede kullanılmasına devam edilmektedir. Enfekte olan kişilerin iyileştirilebilmesi için, tamamıyla güvenilir bir tedavi olmaksızın COVID-19, antimalaryal ilaçlar ve hatta Ebola virüsüyle savaşmak için tasarlanmış ilaçlarla tedavi edilmeye çalışılmaktadır (Strielkowski, 2020). Hasta sayısının artması ve enfekte olmuş kişilerin tespitinde yaşanan gecikmeler nedeniyle de hastane taşıma kapasiteleri ve sağlık çalışanlarının üzerindeki yük de sınırı aşma noktasına gelebilmektedir. Bu durum sağlık çalışanları üzerinde hem mesleki hem de vicdani baskı unsuru yaratmakta ve sağlık çalışanlarının fiziki ve ruhsal sağlıkları üzerinde olumsuz etkiler yapabilmektedir. Bu etkilerin yanı sıra güncel durumda sağlık çalışanları salgının merkezinde kurtarıcı olarak yer aldıkları için enfeksiyon kapma riskleri de diğer bireylere kıyasla çok yüksek olmaktadır.

Literatürde COVID-19 sürecinde sağlık çalışanları üzerinde yapılan çalışmalar incelendiğinde genel olarak sağlık çalışanlarının ruhsal ve fiziksel sağlıkları ile ilgili çalışmalar göze çarpmaktadır (Bknz. Saatçi, 2020; Sakaoğlu vd., 2020; Yürük Bal ve Çelik, 2020; Yücesan ve Özkan, 2020; Pala ve Metintas, 2020; Polat ve Coşkun, 2020; Enli Tuncay, Koyuncu ve Özel, 2020). Türkiye'de Hacimusalar vd. (2020) tarafindan yapılan çalışmada COVID-19 salgınında sağlık çalışanı olan ve olmayan kişilerin kaygı ve umutsuzluk seviyeleri karşılaştırılmıştır. Bulgular, sağlık çalışanlarının sağlık çalışanı olmayanlara göre umutsuzluk ve kaygı durumlarının daha yüksek olduğu ve hemşirelerin umutsuzluk düzeyinin hem doktorlar hem de diğer sağlık çalışanlarından daha yüksek olduğu yönündedir. Öte yandan Dai vd. (2020), salgının merkezi olan Çin'de yaptıkları bir araştırmada sağlık çalışanlarının risk algısı, hastalığa maruz kalma deneyimleri ve psikolojik durumlarının belirlenmesini amaçlamışlardır. Çalışma sonuçlarına göre, sağlık çalışanlarının temel endişeleri; meslektaşlarının ve aile üyelerinin virüse maruz kalması, koruyucu önlemlerin yeterli olmaması ve tıbbi şiddet iken; psikolojik sıkıntıları ise Wuhan'da çalışmak, birinci basamakta tedavilere katılmak, izole yaşantı, meslektaş ve aile üyelerinin enfekte olması şeklindedir. Benzer bir şekilde, Di Tella vd. (2020) ve Chew vd. (2020) araştırmalarında, COVID-19 servislerinde çalışan sağlık uzmanlarının, diğer sağlık birimlerinde çalışanlara göre daha yüksek seviyelerde depresif semptomlar ve travma sonrası stres belirtileri 
bildirdiklerini ifade etmişlerdir. Araştırmada sağlık çalışanları stresin nedeni olarak virüsün acımasızca yayılması, yeterince dinlenememeleri, sürekli enfekte olma tehdidi, iş yükü, tıbbi koruyucu ekipman eksikliği, aileden sık sık izolasyon, hastaların ve meslektaşların ölümü gibi travmatik olaylara uzun süre maruz kalma gibi nedenler belirtmişlerdir. Que vd. (2020), COVID-19 salgını sırasında sağlık çalışanları arasında psikolojik sorunların yaygın olduğunu, olumsuz bilgilere maruz kalmanın ve ön saflarda yer almanın psikolojik sorunlar için risk faktörleri olarak göründüğünü bildirmektedir. Wang vd. (2020) bu etkilerin rahatsızlığı içinde olsalar da sağlık çalışanlarının COVID-19 salgını sırasında mesleki bağlılıklar ve fedakârlıkları sayesinde streslerini azaltabildikleri sonucunu da çalışmalarında vurgulamışlardır.

Braquehais vd. (2020) ve Shaukat vd. (2020) sağlık çalışanlarında salgın nedeniyle gelişen mental ve fiziksel etkiler ile ilgili yaptıkları literatür derlemelerinde sağlık çalışanlarının yüksek riskli bir departmanda çalışmak, tanı konulan aile üyesi, hastalarla temas öncesi ve sonrası yetersiz el hijyeni, uygunsuz kişisel koruyucu ekipman kullanımı, hastalarla yakın temas, uzun günlük temas saatleri ve korunmasız kalma durumlarını önemli risk faktörleri olarak gördükleri, sağlık çalışanlarının yüksek düzeyde depresyon, anksiyete, uykusuzluk ve stres yaşadığı ve bu durumdan kadın sağlı çalışanları ve hemşirelerin daha fazla etkilendiği sonuçlarına ulaşmışlardır.

Chirica vd. (2020) sağlık çalışanlarının salgın süresince yükssek stres, tükenmişlik ve travma sonrası stres bozukluğu riskleri altında olduklarını ve mental sağlıklarını korumak için önleyici tedbirlerin ve psikolojik müdahale planının zorunlu iş sağlı̆̆ gözetim programı dahilinde ele alınmasını ve bu programın işyerinde ruh sağlığı uzmanları ile işbirliği içinde işyeri hekimleri tarafından yürütülmesi gerektiğini belirtmektedirler. Aynı zamanda açık iletişim, yeterli kişisel koruyucu donanıma erişim, yeterli dinlenme ve hem pratik hem de psikolojik desteğin de sağlık çalışanlarının psikolojilerini onarmaya yardımcı olduğu söylenebilir (Gold, 2020). Ancak tüm bu mesleki bağl1lık ve özveriye rağmen Taylor vd. (2020), sağlık hizmeti çalışanlarından korkma ve kaçınmanın COVID-19'un yaygın ama az bilinen bir özelliği olduğunu belirtmişlerdir. Buna göre çalışmaya katılanlar, sağlık çalışanlarının özgürlüklerine kısıtlamalar (toplumdan ve ailelerinden ayrı tutulması gibi) getirilmesi gerektiğine inanmakta ve enfeksiyon korkusuyla sağlık çalışanlarından kaçındıklarını belirtmektedirler. Bu şekilde sağlık çalışanlarından kaçınan insanların aynı zamanda diğer insanlardan kaçınma, eczanelerden ve süpermarketlerden kaçınma ve evlerini terk etmeme eğiliminde olduklarını da ortaya konmuştur.

Sonuç olarak yapılan çalışmalarda; 
- Sağlık çalışanlarına karşı davranışlarda ve kullanılan sözlerde daha özenli olunması,

- Sağlık çalışanları arasında psikolojik sıkıntı ve tükenmişlik gibi risklerin giderilmesi için yeterli düzeyde ve uzun vadeli destek hizmetler sunulması (Choudhury, 2020; Hall, 2020),

- İşyeri sağlık ve hijyen güvenliğinde iyileştirmeler yapılması (Ogolodom, 2020),

- Sağlık çalışanlarının özel psikolojik durumlar hakkında bilgilendirilmesi,

- COVID-19 hastalarının tedavisinde görev alan hekimler ile hastaların stres, depresyon ve anksiyetelerinin piskiyatri ekipleriyle birlikte değerlendirilmesi (Bohlken, 2020; Spoorthy, 2020),

- Destek personelinin sayısının artırılması, gelirin sağlık çalışanları genelinde iyileştirilmesi, hekimlere değer verildiğinin hissettirilmesi (Heath vd., 2020),

- COVID-19 salgını boyunca sağlık çalışanlarının stresle başa çıkmak, mental ve fiziksel sağlıklarını korumak için fiziksel aktivite ve egzersizlere yönelmelerinin ve çevrimiçi bireysel terapist/danışmanlık hizmetlerine erişimlerinin kolaylaştırılması Shechter vd. (2020) şeklinde bazı öneriler yer almaktadır.

\section{Yöntem}

Bu çalışmanın amacı, Türkiye'de hizmet veren sağlık çalışanlarının 2020 yılında tüm dünyayı etkisi altında alan COVID-19 salgını hakkındaki düşünce ve deneyimlerini araştırmaktır. Sağlık çalışanlarının COVID-19 virüsüne ilişskin ortaya koyduğu görüşler bu çalışmada; (i) düşünce ve tanımlamalar, (ii) virüsün olası nedenleri, (iii) virüsten korunma yöntemleri, (iv) Türkiye'de yapılan çalışmalar (v) dünyada yapılan çalışmalar ve (vi) sosyal medyanın virüs algısına etkisi olmak üzere altı temel kategoride incelenmiştir. Bu kategoriler bağlamında elde edilen verilerle sağlı çalışanlarının COVID-19 salgını hakkındaki sosyal, duygusal ve sembolik temsillerini ortaya koymak amaçlanmıştır.

\section{1. Çalışmanın Yöntemi}

COVID-19 virüsüne tüm dünya ülkeleri ve insanları hazırlıksız yakalanmışlardır. Salgının yayılma biçimi göz önüne alındığında; konunun sadece sağlık boyutuyla ilgili olmadığı ve hem sosyal hem de duygusal içerik taşıdığ 1 görülmektedir. Bu nedenle söz konusu salgına ilişkin temsilleri doğru bir biçimde anlamak ve incelemek ihtiyacı bulunmaktadır. COVID-19 virüsü ve salgının yaratmış olduğu etkinin ve anlamın derinlemesine ortaya çıkarılması amacıyla bu çalışmada nitel araştırma yöntemi ve olgu bilim deseni kullanılmıştır. Veriler, 2020 yılının Nisan ayında uzaktan erişim yoluyla görüşmeler yapılarak ve çevrimiçi görüşme formları aracılığıyla toplanmıştır. 


\section{2. Çalışmanın Evreni ve Örneklemi}

Amaçlı örneklem yöntemi kullanlan çalışmada, İzmir'de hizmet veren sağlık çalışanları arasından 57 kadın ve 10 erkek olmak üzere toplam 67 katılımcı belirlenmiştir. Örneklemin yaş ortalaması 42,4 olup katılımcıların meslek ve cinsiyet dağılımı aşağıdaki tabloda sunulmaktadır:

Tablo 1. Araştırmaya Katılan Katılımcıların Cinsiyet ve Meslek Dağılımı

\begin{tabular}{|c|c|c|c|c|c|c|c|c|}
\hline & Tıp Hekimi & Hemşire & Ebe & $\begin{array}{c}\text { Sağlık } \\
\text { Memuru }\end{array}$ & $\begin{array}{c}\text { Sağlık } \\
\text { Teknikeri }\end{array}$ & Eczacı & Diğerleri & Toplam \\
\hline Kadın & 21 & 25 & 3 & 1 & 1 & 3 & 3 & 57 \\
\hline Erkek & 4 & 3 & 0 & 1 & 2 & 0 & 0 & 10 \\
\hline $\begin{array}{c}\text { Mesleğe Göre } \\
\text { Toplam } \\
\text { Katılımcı }\end{array}$ & 25 & 28 & 3 & 2 & 3 & 3 & 3 & 67 \\
\hline
\end{tabular}

\subsection{Veri Toplama Araçları}

Çalışmada, Çırakoğlu (2011)'nun Türk Psikoloji Dergisi'nde yayınlanmış makalesinde bulunan önermelerden esinlenerek oluşturulan soru formu veri toplama aracı olarak kullanılmıştır. Söz konusu soru formu iki bölümden oluşmaktadır. Birinci bölüm olan demografik bilgiler bölümü; sağlık çalışanının yaşı, cinsiyeti, mesleği hakkında bilgi elde etmeye yöneliktir. İkinci bölüm ise katılımcıların COVID-19 virüsüne ilişkin düşünce ve tanımlamaları, salgının nedenleri hakkındaki görüşleri, korunma ve kontrol altına alma yöntemleri konusundaki önerileri, Türkiye'de ve dünyada yapılan çalışmalara ilişkin fikirleri ve son olarak hastalık bağlamındaki sosyal etkileşimlere ilişkin görüşleri hakkında bilgi edinmeye yöneliktir.

Katılımcıların görüşme formunda verdikleri bilgilerle COVID-19 salgınına yönelik algıları belirlenmeye çalışılmış ve söz konusu algının katılımcıların hastalıkla ilgili sosyal temsillerine ne derece etki ettiği tespit edilmeye çalışılmıştır. Veri toplama aracının ikinci bölümünde katılımcılara yönlendirilen sorular çalışmanın tematik kodlama işleminde de kullanılmıştır. Bu sorular aşağıdaki gibidir:

- COVID-19 salgını hakkında ne düşünüyorsunuz?

- Bu hastalığın sebebi sizce ne olabilir?

- Salgınla ilgili Türkiye'de yapılan çalışmalar hakkında ne düşünüyorsunuz?

- Salgınla ilgili dünyada yapılan çalışmalar hakkında ne düşünüyorsunuz?

- Salgından korunmak için yapılması gerekenler hakkında düşünceleriniz nelerdir?

- COVID-19 ile ilgili mesleğinizin gereklerini yerine getirirken hangi düşünceler ve duyguları yaşıyorsunuz? 
- COVID-19 ile ilgili olarak medyada ya da sosyal medyada dolaşan ya da çıkan haberlere maruz kalıyor musunuz? Tepkiniz ne oluyor?

- Salgın sürecinde bir sağlık çalışanı olarak yaşadığınız ve sizi iyi hissettiren en olumlu olayı anlatır misinız?

- Salgın sürecinde bir sağlık çalışanı olarak yaşadığınız ve size kötü hissettiren en olumsuz olayı anlatır misiniz?

Çalışmada COVID-19 algısı hakkında kullanılan tema ve temsiller aşağıda gösterilmektedir:

Tablo 2. COVID-19 algisı hakkında kullanılan tema ve temsiller

\begin{tabular}{|c|c|}
\hline \multicolumn{2}{|c|}{ Sağlık Çalışanlarının Temsilleri ile COVID-19 } \\
\hline COVID-19 Algisl & Temsiller \\
\hline 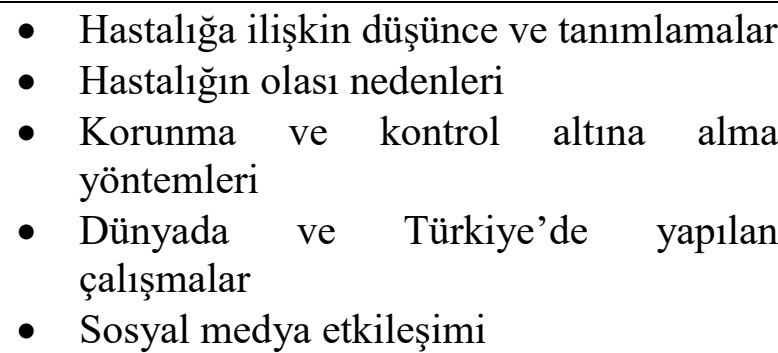 & $\begin{array}{l}\text { - Sosyal } \\
\text { Olumlu ve olumsuz olaylar } \\
\text { - Duygusal } \\
\text { Olumlu ve olumsuz duygular } \\
-\quad \text { Sembolik } \\
\text { COVID-19 virüsüne ait sembol(ler) }\end{array}$ \\
\hline
\end{tabular}

\section{Bulgular ve Yorumlar}

Çalışmanın temasını oluşturun sorular kapsamında elde edilen veriler Maxqda Analytics Pro 2018 programı aracılığıyla analiz edilmiştir. Maxqda Analytics Pro 2018 programı, araştırma verilerinin analiz edilmesine yardımcı olmakta ve bu çalışma özelinde COVID-19 salgınına yönelik sağlık çalışanlarının görüş ve düşüncelerinin görsel araçlar yoluyla sunulmasını desteklemektedir. Programın görsel araçları kullanması okuyucunun olguyu kolaylıkla anlaması, söz konusu olguya ilişkin farklı görüş ve tanımlamaları birlikte değerlendirmesine olanak sağlaması bakımından tercih edilmiştir. $\mathrm{Bu}$ çalışmada analizlerde ve verilerin okuyucuya sunulmasında; Maxqda Analytics Pro 2018 programının sunduğu görsel araçlardan Etkileşimli Hayat Ağacı, Kod - Alt Kod Modeli ve Kod İlişkileri Haritası kullanılmıştır.

\subsection{Etkileşimli Hayat Ă̆acı Modeli}

Etkileşimli Hayat Ăgacı, Maxqda Analytics Pro 2018 programı kapsamında sunulan görsel araçlardan biridir. Etkileşimli Hayat Ağacı, katılımcıların en çok kullandığı sözcükleri 
kombinasyonları ile birlikte seçerek bir ağaç şekline dönüştürmekte ve böylelikle söz konusu sözcükler aracılığıyla okuyucuya ele alınan olgu hakkında fikir vermektedir. Sözcüklerden çıkan ağaç dallarının sayısı ne kadar fazla ise, sözcügün o kadar çok kombinasyon ile birlikte kullanıldığı kabul edilmektedir. Çalışmaya katkı veren 67 katılımcının görüşme formları analiz edildiğinde söz konusu formlarda en çok kullanılan dört sözcük belirlenmiştir. Katılımcıların bu sözcükler ile birlikte kullandıkları kombinasyonlar ise aşağıda görselleştirilmiştir.

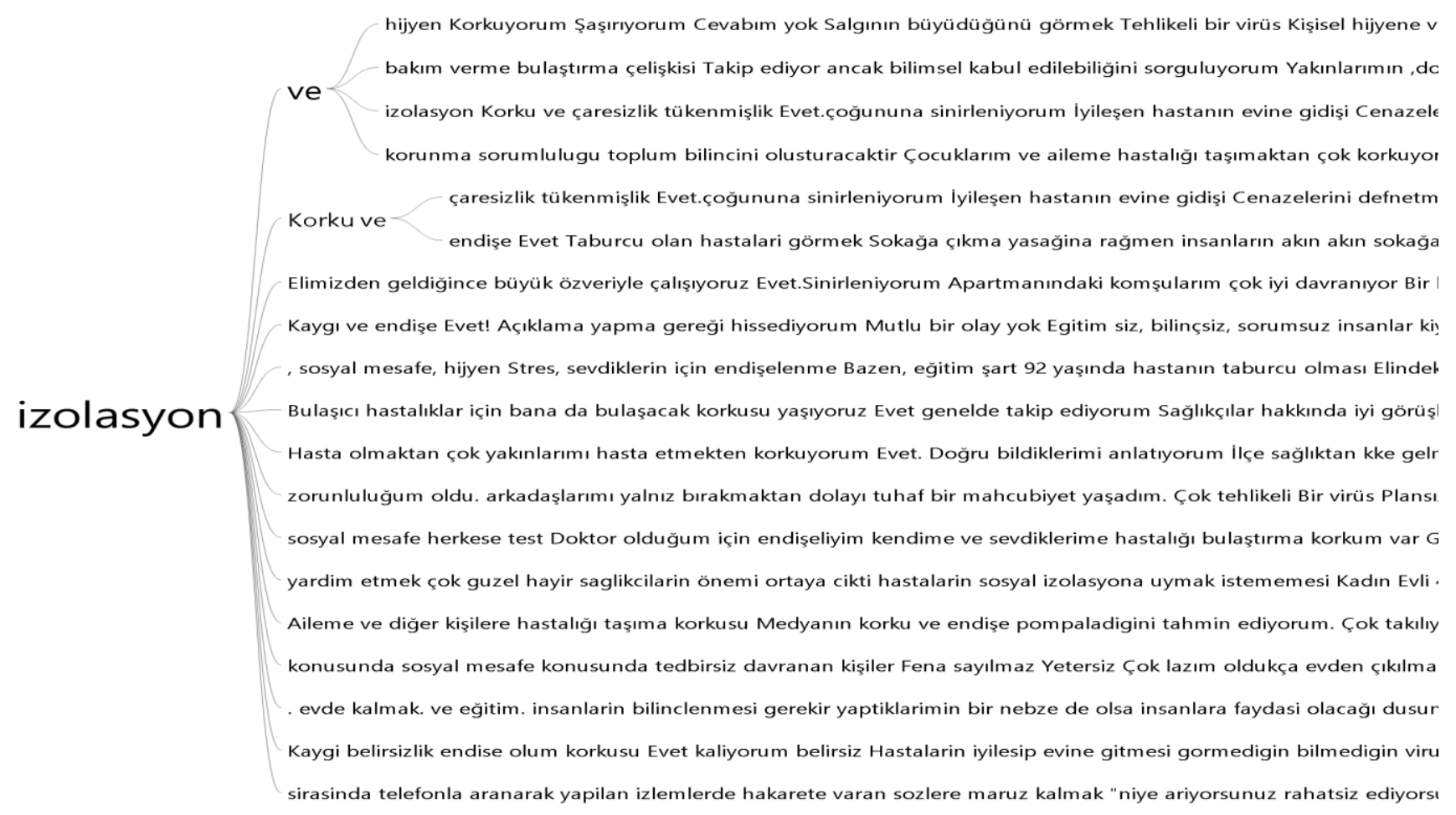

Şekil 1. Sağlık Çalışanlarının COVID-19 Salgınına İlişkin Etkileşimli Hayat Ağacı Modeli İzolasyon 
Kurt Yılmaz, B., Güler, M. E., Sürgevil Dalkılıç, O. / Journal of Yasar University, 2021, 16/62, 960-981

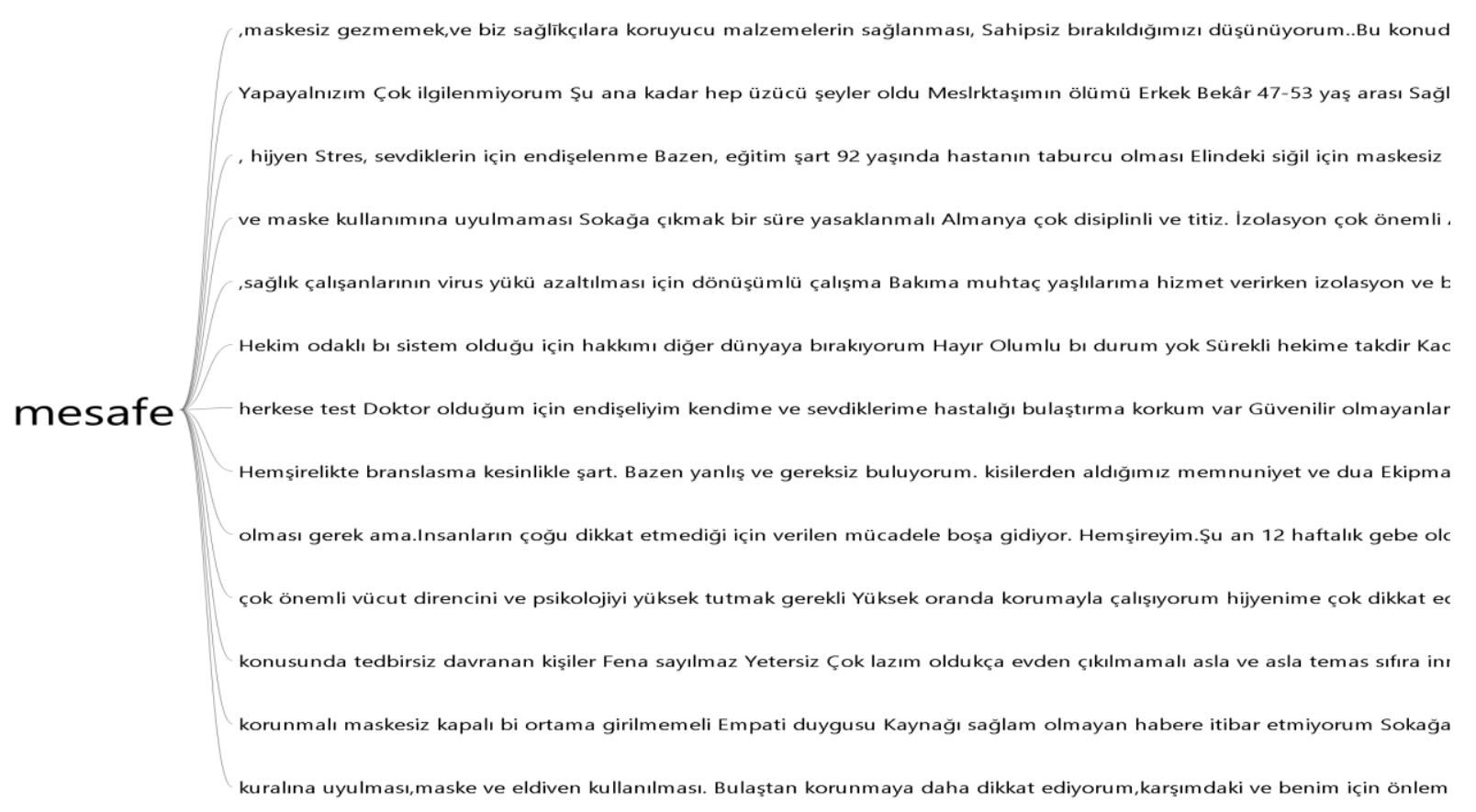

\section{Şekil 2. Sağlık Çalışanlarının COVID-19 Salgınına İlişkin Etkileşimli Hayat Ağacı Modeli-} Mesafe

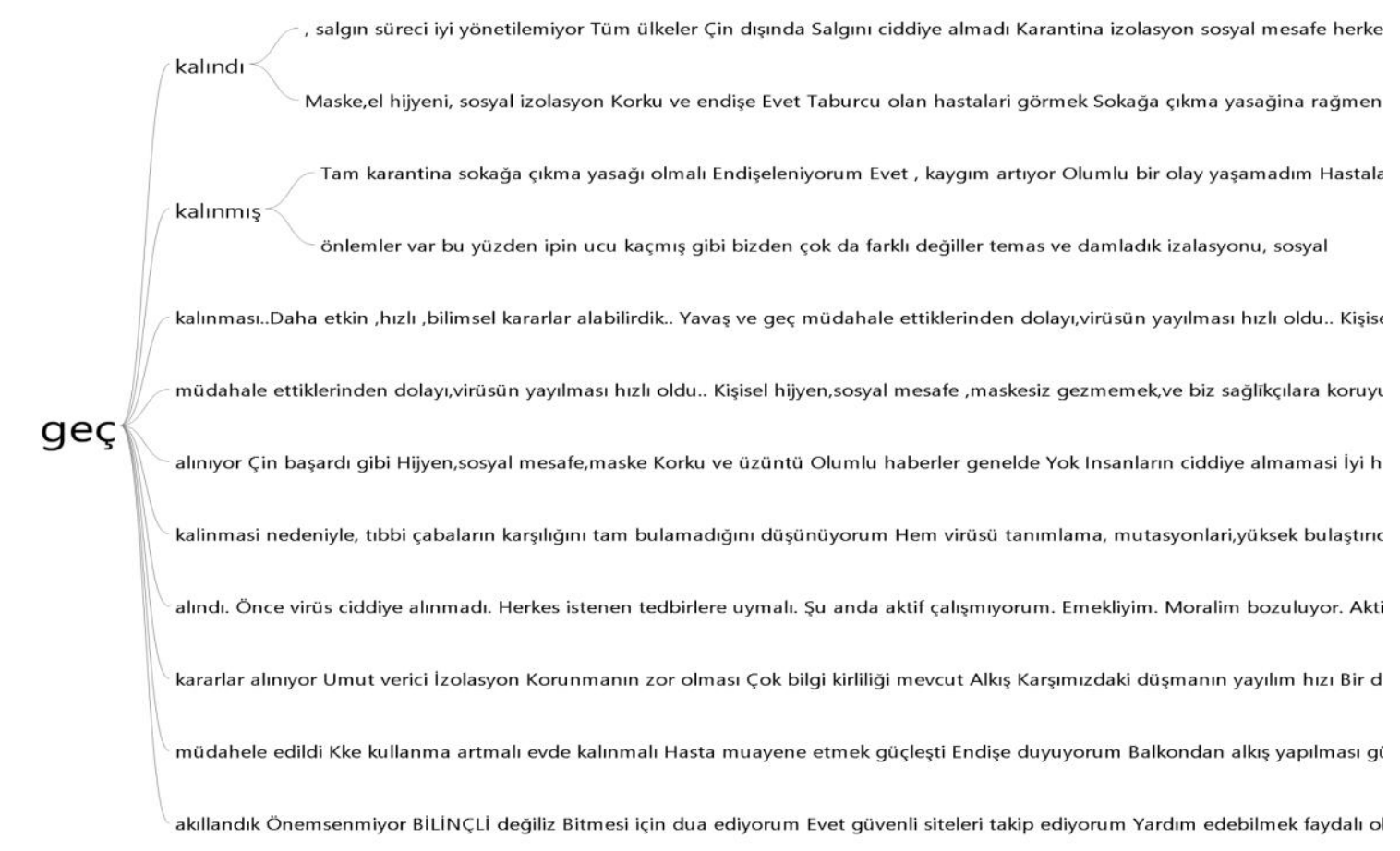

Şekil 3. Sağlık Çalışanlarının COVID-19 Salgınına İlişkin Etkileşimli Hayat Ağacı ModeliGeç 


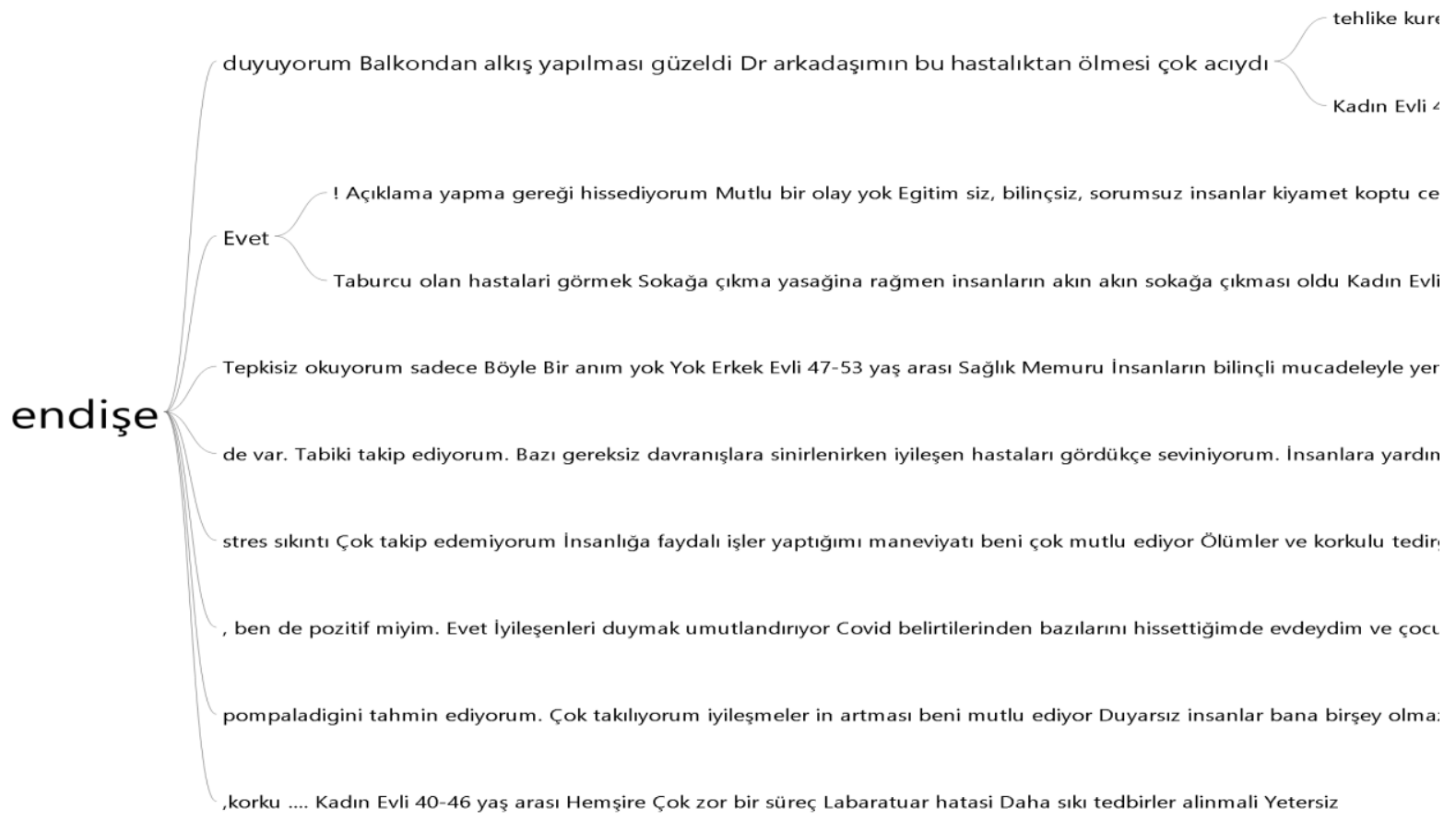

Şekil 4. Sağlık Çalışanlarının COVID-19 Salgınına İlişkin Etkileşimli Hayat Ağacı ModeliEndişe

\subsubsection{Să̆lık Çalışanlarının Etkileşimli Hayat Ă̆acı Modeli Yorumlaması}

Katılımcıların görüşme formları analiz edildiğinde izolasyon, mesafe, endişe ve geç sözcüklerinin en çok kullanılan sözcükler olduğu tespit edilmiştir. Diğer bir deyişle katılımcıların görüşme formunda üzerinde durduğu konular bu sözcükler etrafında şekillenmektedir. Çalışmaya katkı veren sağlık çalışanlarının tamamı COVID-19 virüsünün bulaşıcılığına dikkat çekmektedir. Araştırmaya katılan sağlık çalışanları; salgın karşısında bireylerin virüsün bulaşıcılığından korunmak için izolasyon ve toplu alanlarda mesafeyi korumalarına dikkat çekmektedir. Sağlık çalışanların aynı zamanda; salgının hem toplum hem de sağlık çalışanları üzerinde endişe yarattığına, dünyada yapılan çalışmaların virüsle mücadelede konusunda geciktiğine vurgu yapmaktadır. Söz konusu geç kalınma durumu, tüm dünyada ilk kez yaşanması nedeniyle virüsün bilim insanlarınca yeteri kadar tanınmaması ile ilişkilendirilmektedir.

\subsection{Kod - Alt Kod Modeli}

Maxqda Pro Analytic 2018 programının okuyucuya sunduğu ve bu çalışmada yararlanılan ikinci görsel araç Kod - Alt Kod Modeli'dir. Bu modelde katılımcılardan elde edilen veriler, araştırmacının daha önceden tema bağlamında belirlediği kodlara uygun olarak kodlanır. Katılımcı belgelerinde en çok kodlanan temalar belge veya belge grupları bazında 
görselleştirilerek sunulur. Bu bölümde çalışmaya katkı veren tıp hekimleri ve hemşirelerden elde edilen veriler birer belge grubu olarak kabul edilmektedir.

Söz konusu iki belge grubu kodlar bazında analiz edilerek çalışmanın tematik kodları eşliğinde görselleştirilerek sunulmaktadır.

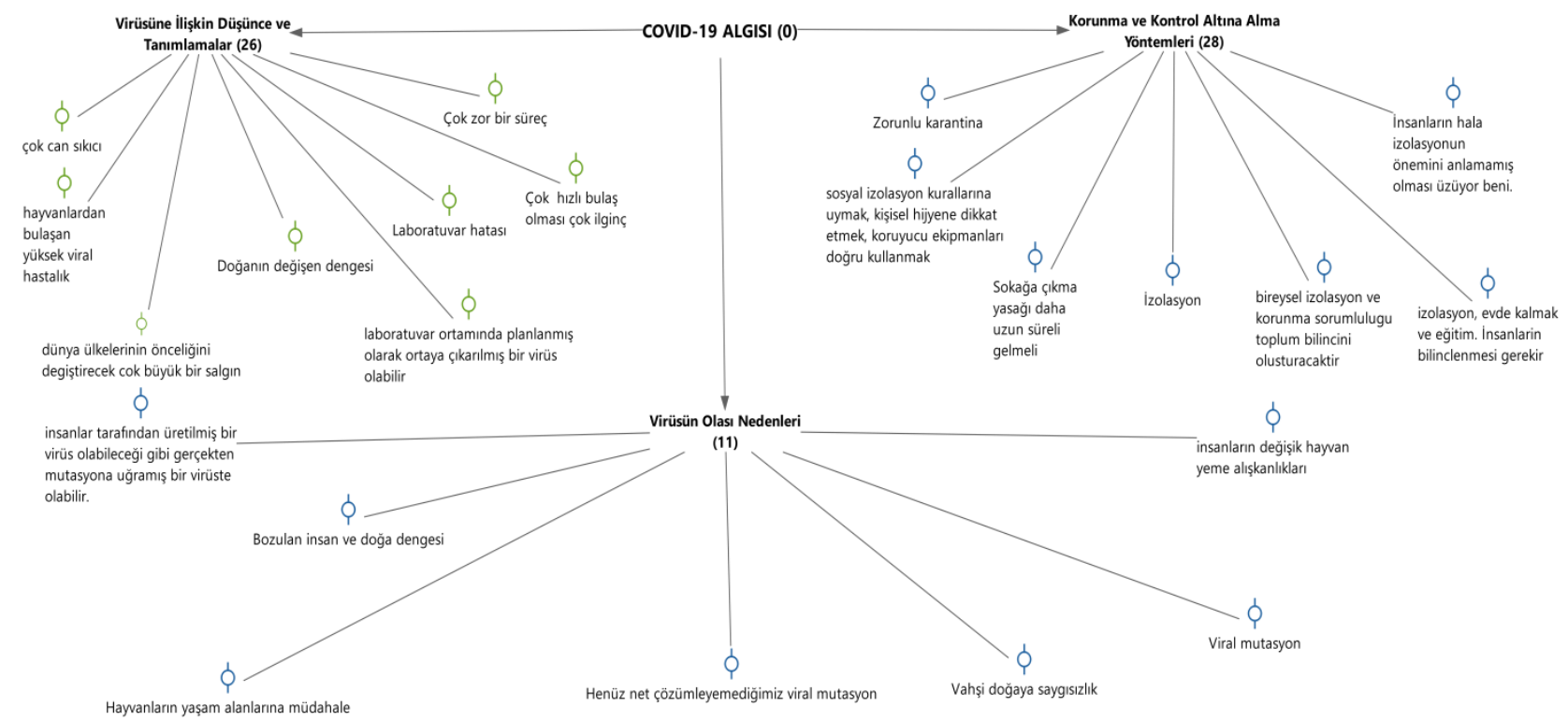

Şekil 5. Tıp Hekimlerinin COVID-19 Algısına İlişskin Kod - Alt Kod Modeli

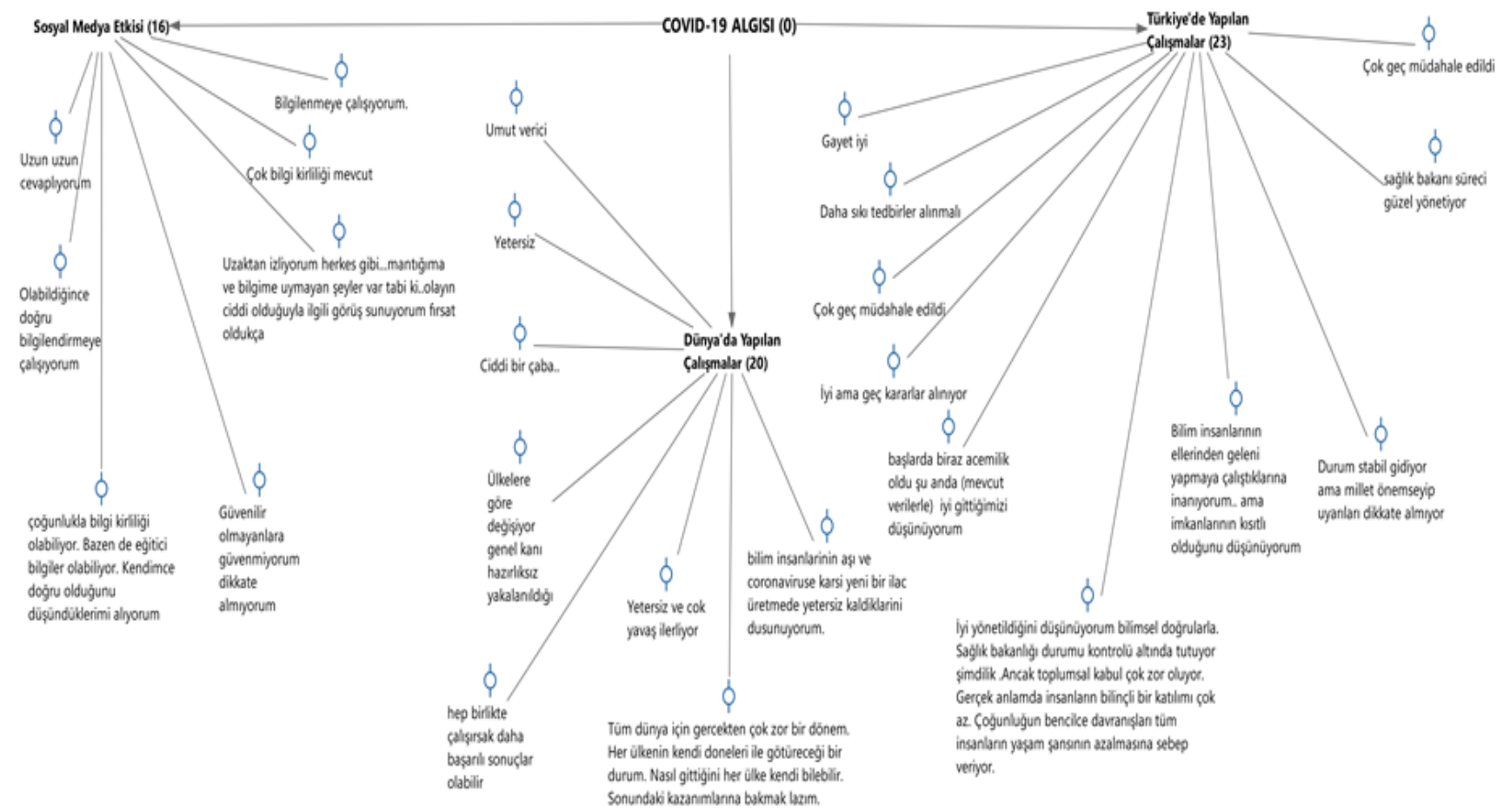

Şekil 6. Tıp Hekimlerinin COVID-19 Algısına İlişkin Kod - Alt Kod Modeli (Devamı) 


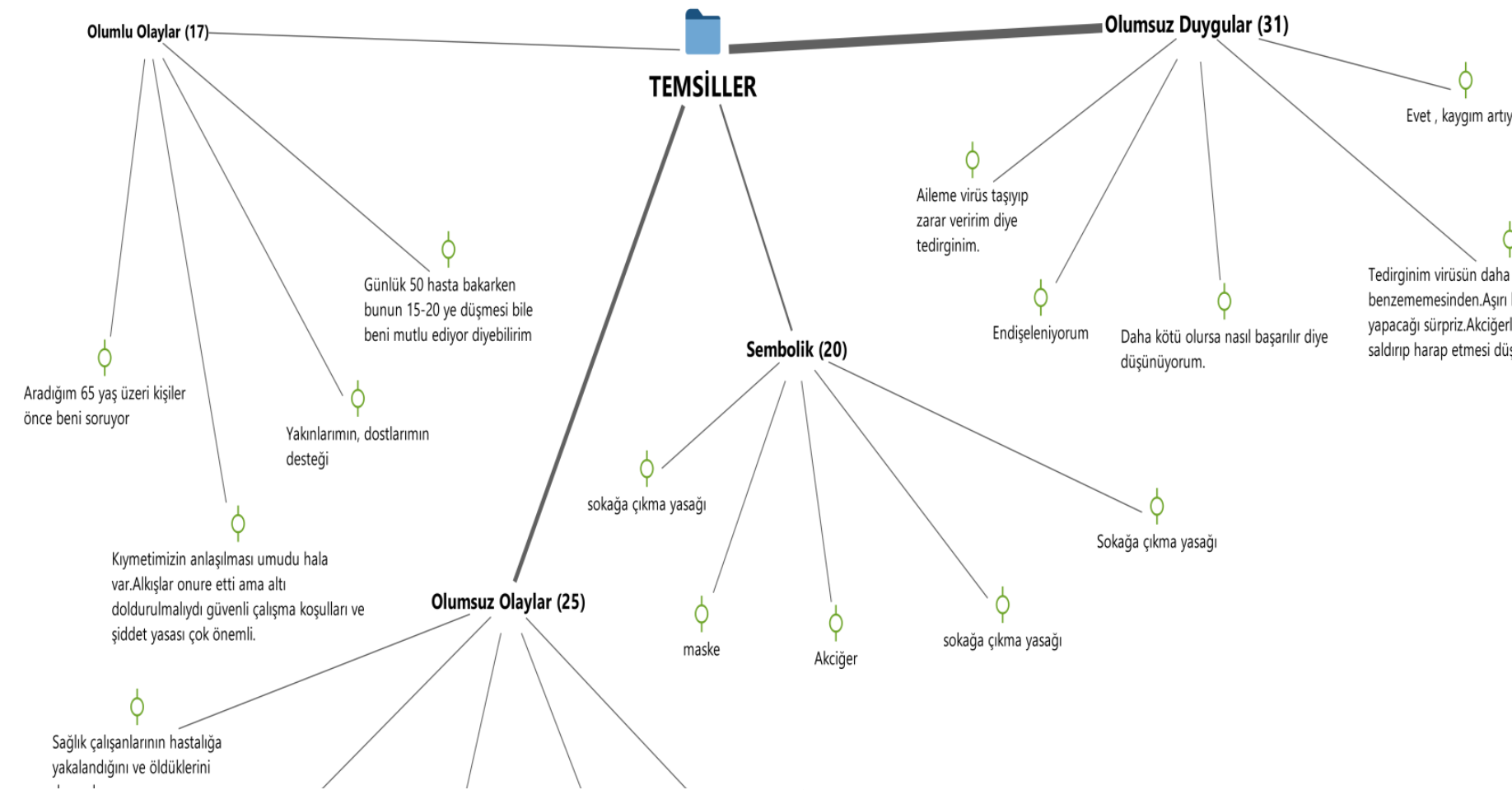

Şekil 7. Tıp Hekimlerinin COVID-19 Temsiline İlişkin Kod - Alt Kod Modeli

\subsubsection{Hekimlerin COVID-19 Algısı ve Temsiline İlişkin Kod - Alt Kod Modeli}

\section{Yorumlamast}

Araştırmaya katkı veren hekimlerin toplam sayısı 25 tir. Kod-Alt Kod Modeli’nde söz konusu 25 hekimin virüs tanımlamaları, virüsün olası nedenleri, korunma ve kontrol altına alma yöntemleri, Türkiye'de ve dünyada yapılan çalışmalar ile virüse ilişkin sosyal medya haberleri konusundaki görüşlerine başvurulmuştur. $\mathrm{Bu}$ bağlamda hekimlerin neredeyse tamamının söz konusu virüsün bulaşıcılığına dikkat çektiği söylenebilir. "Çok hızlı bulaş olması çok ilginç”, "yüksel viral hastalık” ifadeleri bu tespiti ispatlar niteliktedir. Hekimlerin tamamı virüsten korunma ve virüsü kontrol altına alma yöntemleri konusunda hemfikir görünmektedirler. Sosyal mesafe, izolasyon, maske kullanımı ve hijyen kurallarına uygun davranma söz konusu korunma ve kontrol altına alma yöntemlerinin başında gelmektedir. “Zorunlu karantina”, “İzolasyon”, “Sokağa çıkma yasağı şart”, “Evde kalmak gerekir” ifadeleri hekimlerin koruyucu yöntemler konusunda hemfikir olduğunu göstermektedir.

Hekimlerin sosyal medya kullanımı genellikle bilimsel bilgiye başvurma ve bilimsel bilgiyi paylaşma yönündedir. Bilimsel olmayan bilgiye itibar etmedikleri gibi söz konusu bilginin yayılmasında da aracı olmamaya özen göstermektedirler. Kendilerine yöneltilen soruları araştırma verileri çerçevesinde yorumlayarak gerçeğe en yakın bilgiyi verme konusunda dikkatli davranmaktadırlar. Salgınla mücadele kapsamında Türkiye'de yapılan çalışmaları özverili olarak değerlendirmekte, dünyada yapılan çalışmaların ise ülke özelinde 
değerlendirilmesi gerekliliğine vurgu yapmaktadırlar. Ülkelerin salgına yakalanma tarihlerinin birbirinden farklı olması nedeniyle denenmiş ve başarılı olmuş yöntemlerin seçiminde ve uygulanmasında da farklılıkların bulunduğuna dikkat çekmektedirler. Örneğin Türkiye'nin salgına yakalanma tarihinin diğer ülkelere kıyasla bir miktar daha geç olmasının ilaç, hijyen ve koruyucu ekipmanın tesis edilmesi ve depolanması noktasında avantaj yarattı̆̆ını belirtmektedirler.

COVID-19 virüsüne ilişkin olarak hekimlerin sosyal temsilleri incelendiğinde virüsle mücadele aşamasında olumlu deneyimler edinmiş olsalar bile hiçbir olumlu duygu geliştiremedikleri görülmüştür. "Henüz iyi bir şey yaşamadım" ifadesi olumsuz hislerin genellemesi şeklinde yorumlanmaktadır. Tıp hekimleri salgın sırasında ağırlıklı olarak korku, endişe ve tedirginlik hislerini deneyimlemektedir. Nitekim olumsuz duyguların tanımlamasına bakıldığında söz konusu sözcüklerin önemli miktarda kullandığı görülmektedir. "Endişem artıyor", "Tedirginim", "Ailem için kaygllanıyorum" ifadeleri bu durumu teyid eder niteliktedir. Salgının büyümesi, meslektaşlarının ölümü, kendilerinin veya aile üyelerinin enfekte olma riski yaşadıkları olumsuz olaylar ve endişeler olarak değerlendirilirken, benzer biçimde aile üyelerinin ve çevrenin desteği olumlu olaylar ve durumlar olarak değerlendirilmektedir. Hekimlerin COVID-19 virüsüne ilişkin en çok kullandıkları kelimelerin sembolik temsillerine ilişkin fikir verdiği düşünülmektedir. Diğer bir deyişle hekimlerin virüsü zihinlerinde nasıl somutlaştırdığı araştırıldığında bu temsilin genel olarak korunma ve kontrol altına alma yöntemleri ile ilişkilendirildiği görülmektedir. Virüs ile mücadelede sosyal mesafe, izolasyon, karantina ve sokağa çıkma yasağı yöntemlerinin öne çıkması ilave olarak sosyal medya paylaşımlarında da bu yöntemlerin görselleştirilerek sunulması virüsün sembolik temsilini de oluşturmaktadır.

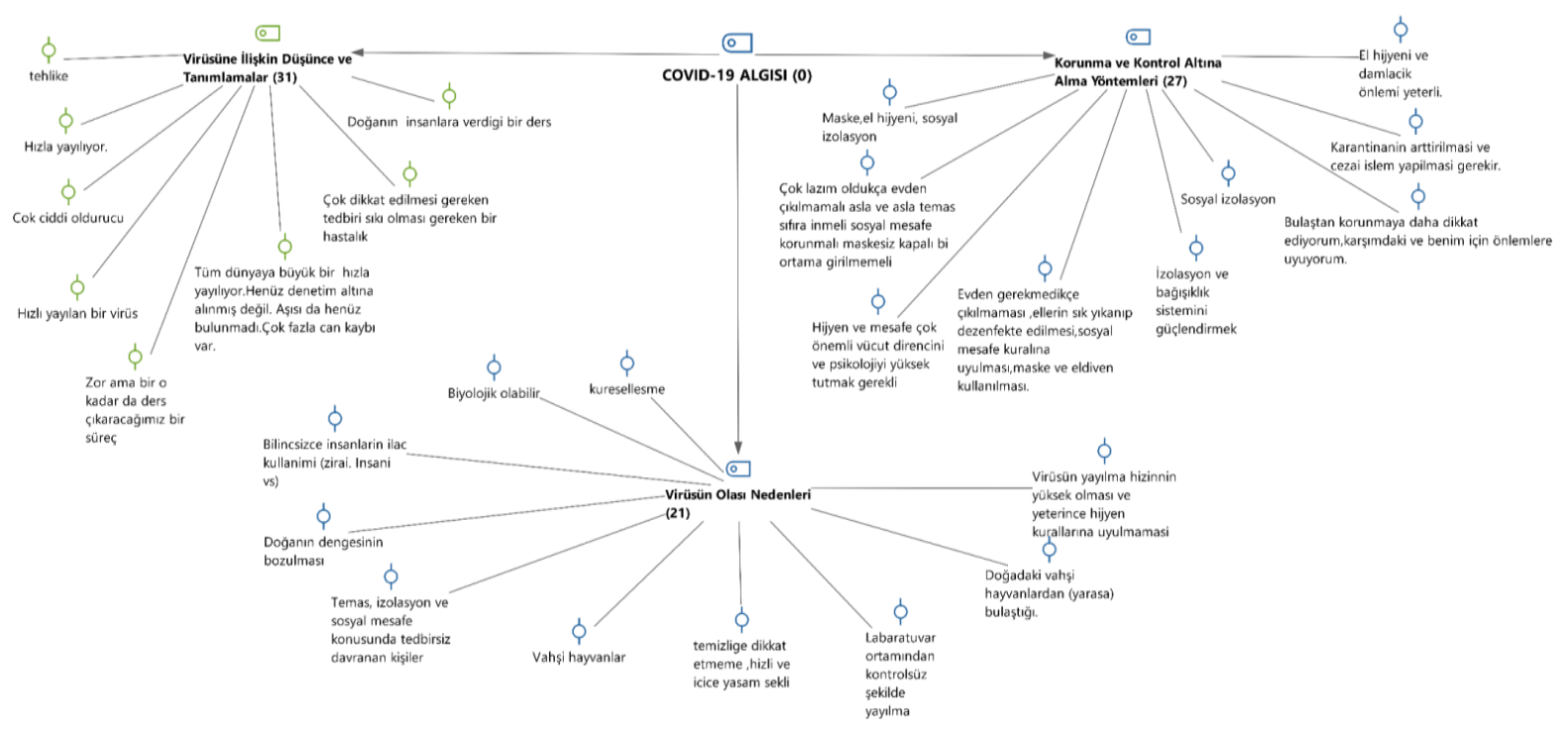

Şekil 8. Hemşirelerin COVID-19 Algısına İlişsin Kod - Alt Kod Modeli 


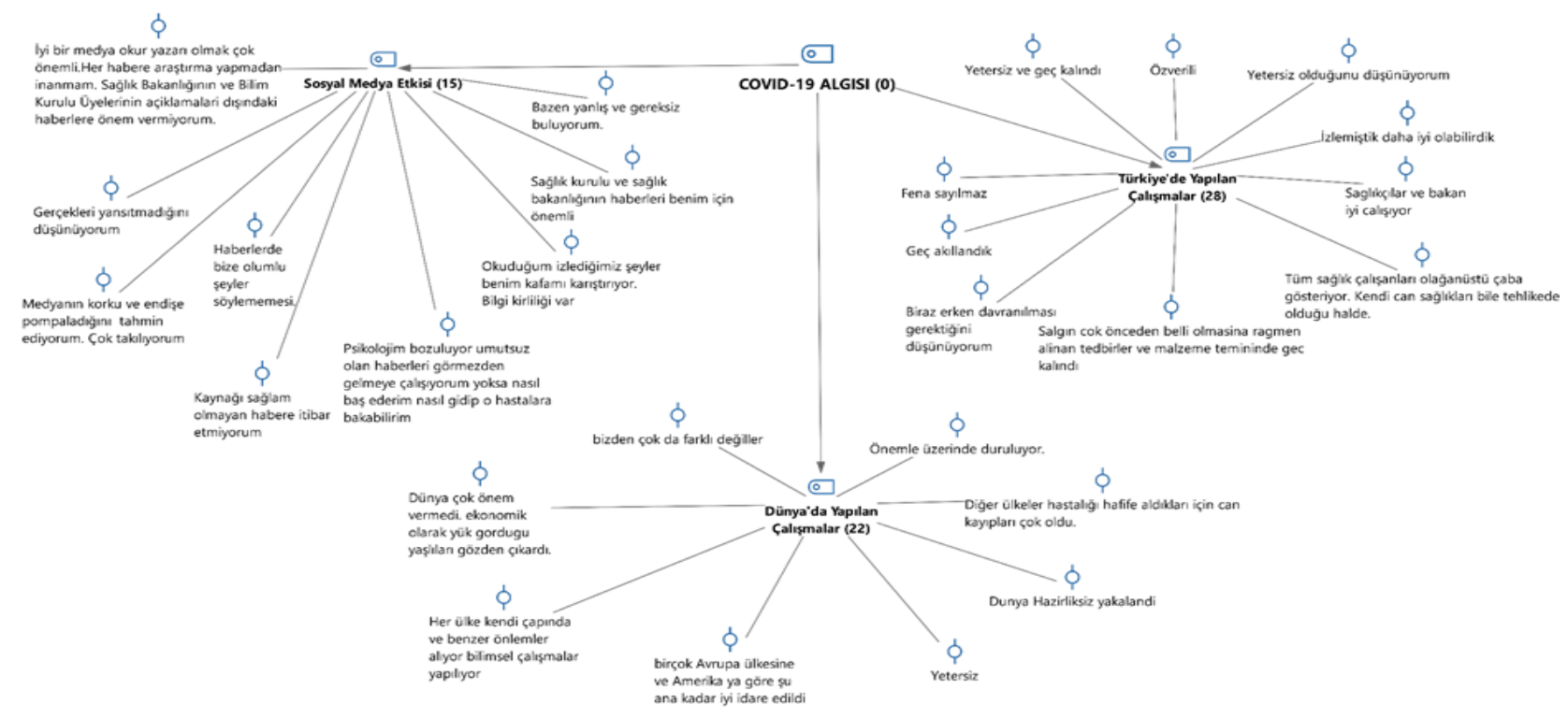

Şekil 9. Hemşirelerin COVID-19 Algısına İlişkin Kod - Alt Kod Modeli (Devamı)

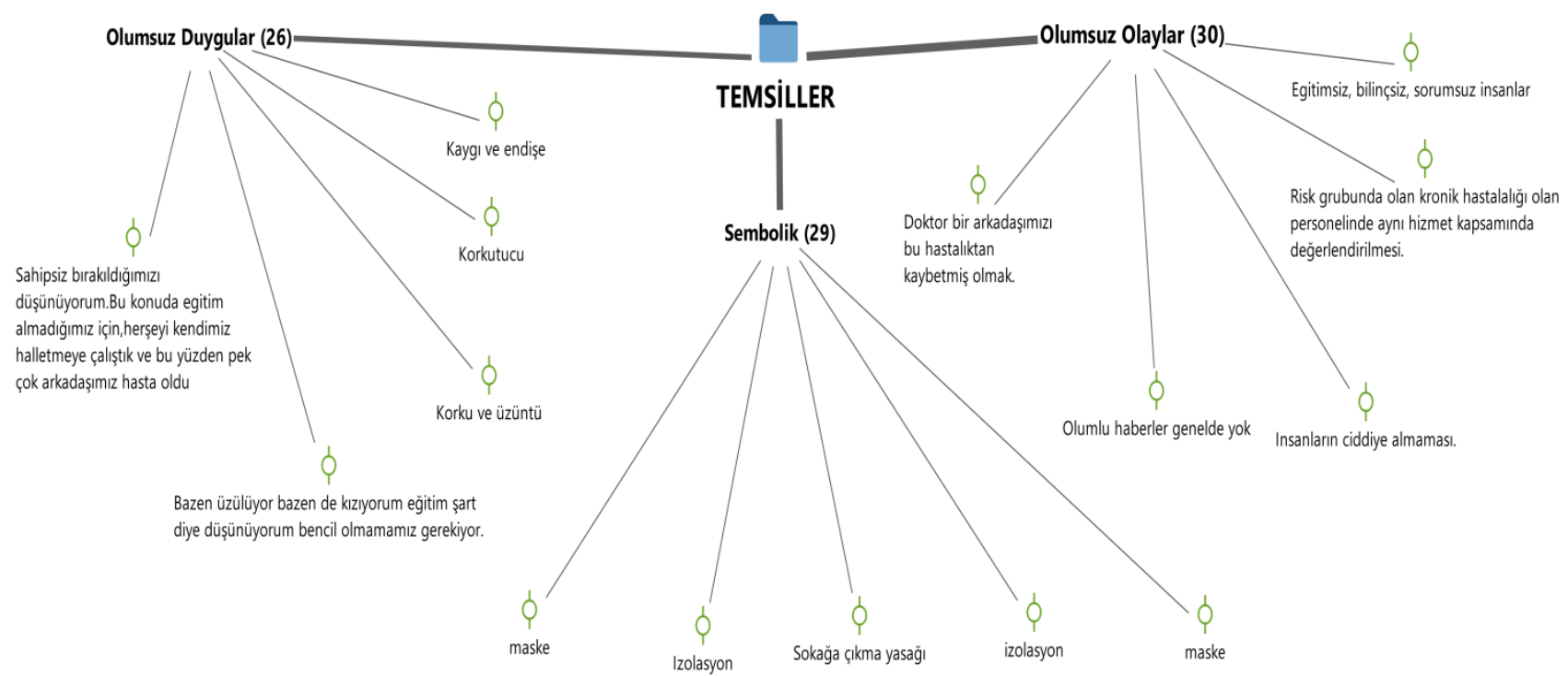

Şekil 10. Hemşirelerin COVID-19 Temsiline İlişkin Kod - Alt Kod Modeli

\subsubsection{Hemşirelerin COVID-19 Algısı ve Temsiline İlişkin Kod - Alt Kod Modeli}

\section{Yorumlamast}

Sağlık çalışanlarından hemşirelerin COVID-19 virüsüne ilişkin temel görüşleri çok hızla yayılan, tehlikeli ve öldürücü bir virüs olduğu yönündedir. "Çok hızla yayılıyor”, "Hızla yayıllyor ve öldürücü”, “Tüm dünyada hızla yayıllyor ve çok fazla can kaybı var” ifadeleri bu tespiti destekler niteliktedir. Bununla birlikte virüsten korunma ve virüsü kontrol altına alma yöntemleri bakımından hem kendi grupları hem de diğer sağlık çalışanları ile aynı fikri 
paylaşmaktadırlar. Sosyal mesafe, izolasyon, hijyen ve maske hemşirelerin önerdiği başlıca korunma ve önlem yöntemleri olarak değerlendirilmektedir.

Sosyal medya paylaşımlarından duygusal anlamda etkilendikleri görülen hemşirelerin bilgi verme veya var olan bilgiyi paylaşma konusunda sosyal medya kullanıcısı olmadığı söylenebilir. "Okuduğum şeyler benim kafamı karıştırıyor”, "Kaynă̆ı sağlam olmayan habere itibar etmiyorum" ifadeleri sosyal medyayı bilgi alma amacıla kullandıklarını destekler niteliktedir. Hemşireler sosyal medya paylaşımlarını yeni bir bilgi olup olmadığını öğrenme amacıyla da takip etmektedirler. Bununla birlikte yeni bilgi konusunda Sağlık Bakanı ve Bilim Kurulu Üyelerini dikkatle takip etmekte, bu bilgilerin doğru ve doyurucu olacağına inanmaktadırlar. COVID-19 virüsüyle mücadele kapsamında dünyada yapılan çalışmalara ilişkin çeşitli fikirleri olan hemşireler, Türkiye'de yapılan çalışmaları genel olarak geç kalınmış olarak değerlendirmektedir. "Geç akıllandık”, "biraz daha erken davranabilirdik”, “daha iyi olabilirdik” ifadeleri bu düşünceyi destekler niteliktedir.

\subsection{Kod İlişkileri Haritası}

Çalışmada kullanılan MAXQDA Pro Analytic 2018 programının okuyucuya sunduğu ve bu çalışmada kullanılan en önemli görsel araçlardan bir diğeri de kod ilişkileri haritalarıdır. Kod ilişkisi haritaları, araştırmacı tarafından belirlenmiş ve atanmış kodların birbirleri ile olan ilişkilerini belgeler bazında analiz ederek görselleştirmektedir. Bu çalışmada kod haritaları oluşturulmasındaki temel amaç; COVID-19 algısını temsil eden altı ana kodun sağlık çalışanlarından hekimler ve hemşireler grubunda hangi kodlar ile yoğun etkileşimde olduğu konusunda okuyucuyu bilgilendirmektir. Örneğin, hekimlik mesleğinde öne çıkan kodun hangisi olduğu ve söz konusu kodun hangi kod veya kodlarla etkileşim içinde olduğu konusunda okuyucu görseller yardımıyla bilgilendirilmektedir.

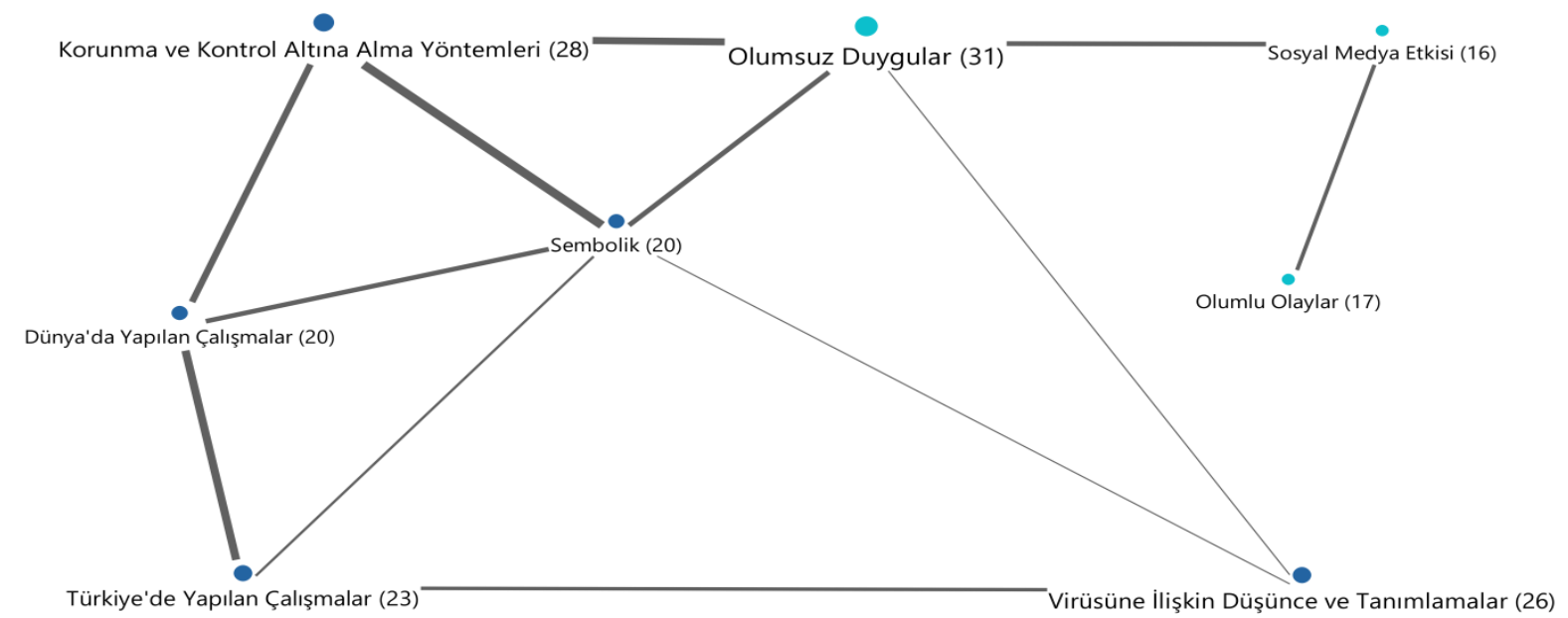

Şekil 11. Hekimlere Ait Kod İlişkileri Haritası 


\subsubsection{Hekimlerin Kod İlişskileri Haritasının Yorumlanması}

Sağlık çalışanlarından tıp hekimlerinin görüşme formlarının analizinde COVID-19 Algısı ana koduna bağlı Korunma ve Kontrol Altına Alma Yöntemleri ile Duygusal Temsiller ana koduna bağlı Olumsuz Duygular alt kodu arasında yoğun bir etkileşim olduğu görülmektedir. Virüsle mücadelede koruyucu tedavi olan aşının araştırma dönemi itibariyle henüz geliştirilmemiş olması ve mevcut korunma yöntemlerinin yetersizliği endişeye neden olmakta ve bu nedenle olumsuz duyguları arttırmaktadır. Diğer bir deyişle, söz konusu iki kod arasındaki yoğun etkileşim, bulunamayan koruyucu tedavi nedeniyle artan olumsuz duygu şeklinde yorumlanmaktadır. Benzer bir biçimde, korunma ve kontrol altına alma yöntemleri kodu ile temsiller koduna bağlı sembolik temsiller ve duygusal temsillere bağlı olumsuz duygular alt kodu ile yoğun bir etkileşim göze çarpmaktadır. Bu durumun temel nedeni yetersiz kalan koruma yöntemlerinin kaygı, endişe ve tedirginlik oluşturması nedeni ile olumsuz duyguları pekiştirmesinden kaynaklanmaktadır. Öte yandan, sosyal medya haberlerinin hem olumsuz duyguların hem de olumlu olayların temsilinde önemli bir rol üstlendiği görülmektedir. Diğer bir deyişle, hekimlerin özverili çabalarının takdir edilerek paylaşımı (örneğin sağlık çalışanlarının alkışlanma videoları) olumlu olaylar olarak değerlendirilirken; virüse karşı tedavi geliştirilememiş olması, dünyada ölüm sayılarının artması ve bu bilgilerin paylaşılması olumsuz duyguların gelişmesine neden olmaktadır.

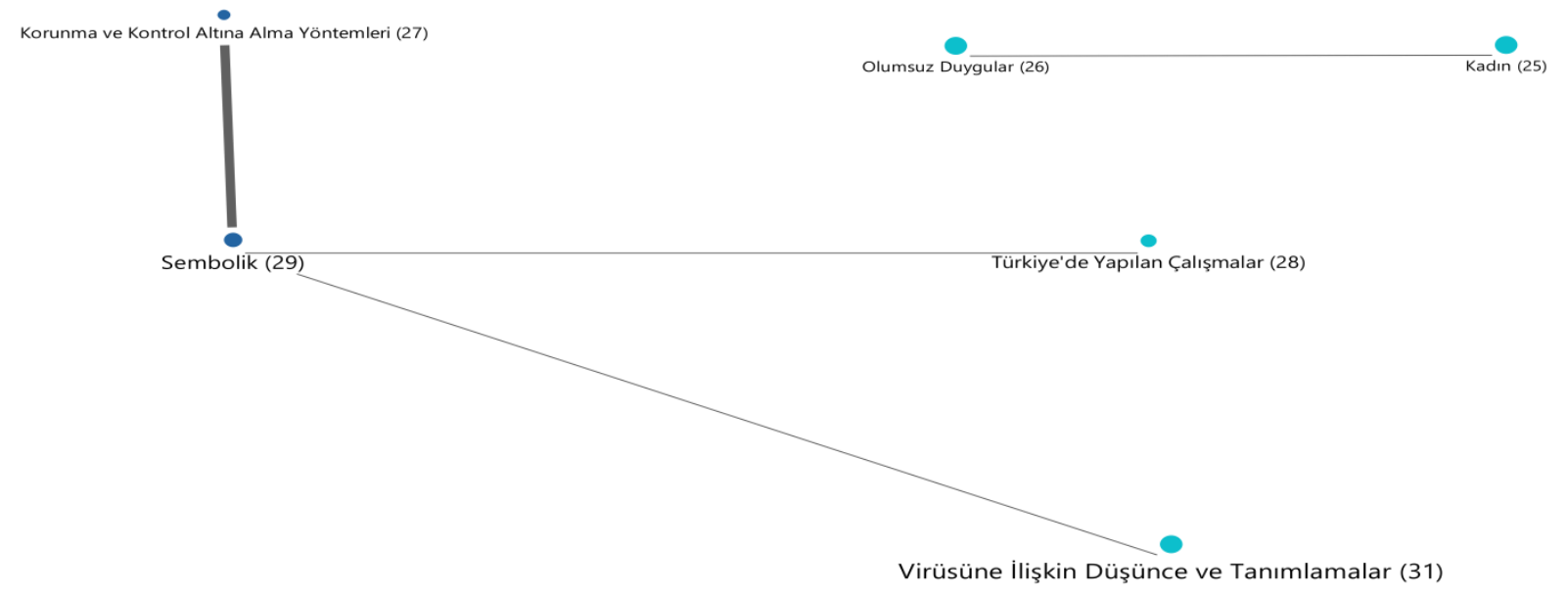

Şekil 12. Hemşirelerin Kod İlişkileri Haritası

\subsubsection{Hemşirelerin Kod İlişkileri Haritasının Yorumlaması}

Hemşirelerin kod ilişkileri haritasında sembolik temsillerin oluşumunda COVID-19 algısının önemli bir rol üstlendiği görülmektedir. Virüse ilişkin düşünceler, virüsle mücadele kapsamında Türkiye'de yapılan çalışmalar, koruma ve korunma yöntemleri sembolik temsil 
oluşumunda önem arz etmektedir. Bununla birlikte duygusal temsil koduna bağlı olumsuz duygular kodunun yoğun biçimde kadın hemşirelerin analizlerinden elde edildiği söylenebilir. Diğer bir deyişle toplam 28 hemşirenin katılım sağladığı çalışmada yer alan 25 kadın hemşirenin tamamı virüse ilişkin olumsuz duygularını dile getirmiştir. Hekimlerde olumsuz duygu ve olumsuz olayların cinsiyetle bağı kurulamamıştır.

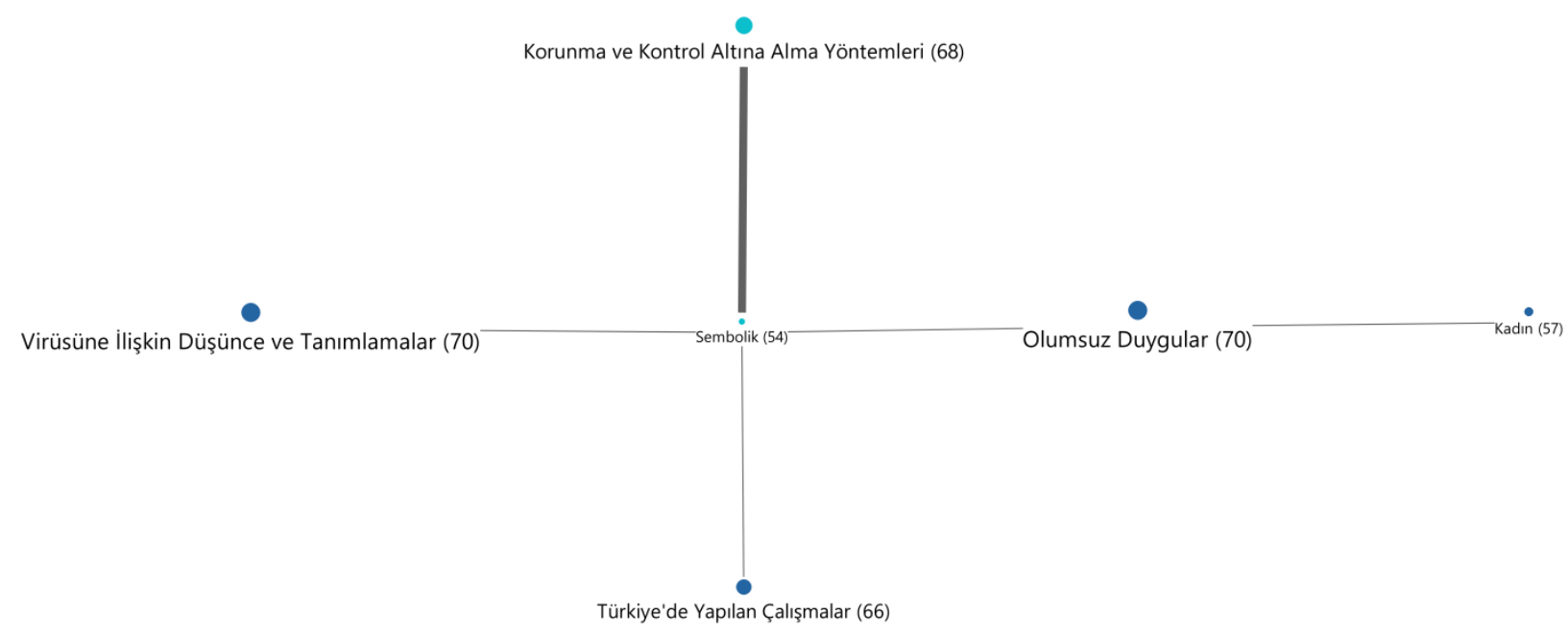

Şekil 13. Tüm Sağlık Çalışanlarının Kod İlişkileri Haritası

\subsubsection{Tüm Sağlık Çalışanlarının Kod İlişkileri Haritasının Yorumlanması}

Çalışmaya katılan tüm sağlık çalışanlarından elde edilen veriler analiz edildiğinde virüse ilişkin düşünce ve tanımlamaların, virüsten korunma ve virüsü kontrol altına alma yöntemlerinin, virüse ilişkin olumsuz duyguların ve ilave olarak Türkiye'de yapılan çalışmaların sağlık çalışanlarının sembolik temsillerinde önemli rol oynadığı söylenebilir. Bununla birlikte olumsuz duygular kodu ile kadın katılımcılar arasında yoğun etkileşim olduğu görülmektedir. Diğer bir deyişle virüse ilişkin olumsuz duygularını ifade eden katılımcılar kadınlardan oluşmaktadır.

\section{Sonuç ve Öneriler}

COVID-19 salgını tüm dünya ülkeleri için önemli kırılma noktalarından biri olmuştur. Söz konusu salgın ile dünya ülkelerinin tamamında toplumsal, ekonomik, sosyal ve kurumsal dönüşümler yaşanmaktadır. Söz konusu değişim ve dönüşüm Türkiye için de geçerlidir. Türkiye'de mevcut sağlık altyapısının güçlü olması, sağlık çalışanlarının gerekli bilgi ve donanıma sahip olması büyük çaptaki ölüm oranlarının önüne geçmiştir. Sağlık çalışanların COVID-19 virüsünün ülkede tespit edildiği 11 Mart 2020 tarihinden itibaren mücadeleci, özverili, çözüm ve yardım odaklı bir yaklaşımla hastalığın teşhis ve tedavi sürecinde çok önemli bir rol üstlendiği bilinmektedir. Salgın süresince hastaneler sağlık ve güvenlik açısından en riskli kurumlar haline gelmiştir. Bu riskler çalışma ortamının doğal sonucu olan 
fiziksel, kimyasal, biyolojik faktörler ve psiko-sosyal yapı olarak ifade edilmektedir. Sağlık çalışanları yaptıkları işin gereği olarak insan sağlığı ile doğrudan ilgili oldukları için stres ve kaygı düzeyleri de yoğun olarak artmaktadır. Diğer bir deyişle sağlık çalışanlarının maruz kaldığı fiziksel, kimyasal ve biyolojik risklerin yanısıra iş baskısı, artan stres düzeyi, oluşan zaman baskısı, eş, evlat, ebeveyn olmanın getirdiği sorumluluk baskısı sağlık çalışanların kaygı düzeylerinde de artışa neden olmaktadır. Bu çalışmada salgının önemli boyutlara ulaştığı İzmir'de görev yapan 67 sağlık çalışanının salgına ilişkin deneyimleri araştırılmıştır.

Çalışmada sağlık çalışanlarının tamamının endişe içinde oldukları tespit edilmiştir. Söz konusu endişe hem salgının büyümesi ve ölüm olaranlarının artması yönünde hem de hastalığın teşhis ve tedavi sürecine katkıda bulunan sağlık çalışanların virüse yakalanarak vefat etmeleri ve kendi ailelerine de virüsü taşıma riskleriyle ilişkilidir. Bu bağlamda sağlık çalışanları topluma sasyal mesafe, maske kullanımı ve hijyen kurallarına uyma noktasında çağrıda bulunmaya devam etmektedirler. Öte yandan sağlık çalışanları salgın dönemi boyunca sadece hastalarının iyileşmesi noktasında olumlu deneyimler geliştirmektedir.

Salgının büyümesi, meslektaşlarının ölümü, kendilerinin veya aile üyelerinin enfekte olma riski yaşadıkları olumsuz olaylar ve endişeler olarak değerlendirilirken, benzer biçimde aile üyelerinin ve çevrenin desteği olumlu olaylar ve durumlar olarak değerlendirilmektedir. Diğer bir deyişle sağlık çalışanları, sadece iyileşmiş hastalarını yaşadıkları olumlu deneyimler olarak görmektedirler.

Hekimlerin sosyal medya kullanımı genellikle bilimsel bilgiye başvurma ve bilimsel bilgiyi paylaşma yönündedir. Hekimler, bilimsel olmayan bilgiye itibar etmedikleri gibi söz konusu bilginin yayılmasında da aracı olmamaya özen göstermektedirler. Kendilerine yöneltilen soruları araştırma verileri çerçevesinde yorumlayarak gerçeğe en yakın bilgiyi verme konusunda oldukça dikkatli davranmaktadırlar. Nitekim aksi durumda toplumda endişe düzeyinin artmasına neden olacaklarını düşünmektedirler.

Sağlık çalışanları salgınla mücadele kapsamında Türkiye'de yapılan çalışmaları özverili olarak değerlendirmekte iken, dünyada yapılan çalışmaların ise ülke özelinde değerlendirilmesi gerekliliğine vurgu yapmaktadırlar. Nitekim ülkelerin salgına yakalanma tarihlerinin birbirinden farklı olması nedeniyle denenmiş ve başarılı olmuş yöntemlerin seçiminde ve uygulanmasında da farklılıkların bulunduğuna dikkat çekmektedirler. Örneğin Türkiye'nin salgına yakalanma tarihinin diğer ülkelere kıyasla bir miktar daha geç olmasının ilaç, hijyen ve koruyucu ekipmanın tesis edilmesi ve depolanması noktasında avantaj yarattığını belirtmektedirler. 
Sağlık çalışanlarının COVID-19 virüsüne ilişkin en çok kullandıkları kelimelerin de sembolik temsillere ilişkin fikir verdiği düşünülmektedir. Diğer bir deyişle hekimlerin virüsü zihinlerinde nasıl somutlaştırdığı araştırıldığında bu temsilin genel olarak korunma ve kontrol altına alma yöntemleri ile ilişkilendirildiği görülmektedir. Virüs ile mücadelede sosyal mesafe, izolasyon, karantina ve sokağa çıkma yasağı yöntemlerinin öne çıkması ilave olarak sosyal medya paylaşımlarında da bu yöntemlerin görselleştirilerek sunulması virüsün sembolik temsilini de oluşturmaktadır.

COVID-19 salgını devam ederken sağlık çalışanları bu mücadelenin ön saflarında olmaya devam etmektedir. $\mathrm{Bu}$ nedenle söz konusu salgın süresince sağlık çalışanlarının fiziksel, sosyal ve psikolojik açıdan güçlendirilmesi için aşağıda sıralanan bazı önerileri geliştirmek mümkündür:

- Sağlık çalışanlarının yeterli koruyucu ekipmana erişiminin sağlanması ve bunun düzenli hale getirilmesi,

- Sağlık kurumlarına giren herkesin COVID-19 belirtileri bakımından taramasının yapılması, riskli bireyler ile sağlık çalışanları için yüz koruyucu ekipmanların güçlendirilmesi (N95 Maske gibi),

- Sağlık kurumlarında hijyen önlemlerinin en üst seviyeye çıkartılması,

- Sosyal mesafenin sağlanması için bariyer önlemine başvurulması,

- Sağlık çalışanlarının yöneticileri ile sürekli iletişim halinde olması,

- Yeterli uyku ve beslenme ihtiyaçlarının karşılanması.

Bu önerilere ek olarak Çetin (2020), COVID-19 salgını boyunca tüm sağlık çalışanlarının tıbbi takibinin yapılmasına da vurgu yapmakta; ayrıca tüm çalışanlara COVID-19 bulaşını önlemeye yönelik eğitim sağlanması ve çalışanların stresine yönelik psikolojik ve davranışsal desteğin verilmesini önermektedir.

$\mathrm{Bu}$ çalışmayla elde edilen veriler, yapılan tartışma ve önerilerin tamamı dikkate alınarak, gelecek çalışmalarda araştırmacılara COVID-19'un sağlık sisteminde ve sağlık çalışanları üzerinde yaratmış olduğu/olacağı uzun vadeli etkileri araştırmaları ve tüm süreçlerde yaşanabilecek dönüşüm üzerine düşünce üretmeleri önerilmektedir. 


\section{KAYNAKÇA}

Bohlken, J., Schömig, F., Lemke, M. R., Pumberger, M., \& Riedel-Heller, S. G. (2020). COVID-19 pandemic: stress experience of healthcare workers-a short current review. Psychiatrische Praxis, 47(4), 190-197.

Braquehais, M. D., Vargas-Cáceres, S., Gómez-Durán, E., Nieva, G., Valero, S., Casas, M., \& Bruguera, E. (2020). The impact of the COVID-19 pandemic on the mental health of healthcare professionals. QJM: An International Journal of Medicine, 113(9), 613-617.

Chew, N. W., Lee, G. K., Tan, B. Y., Jing, M., Goh, Y., Ngiam, N. J., ... \& Sharma, A. K. (2020). A multinational, multicentre study on the psychological outcomes and associated physical symptoms amongst healthcare workers during COVID-19 outbreak. Brain, behavior, and immunity. Volume 88, August 2020, Pages 559-565

Chinazzi, M., Davis, J. T., Ajelli, M., Gioannini, C., Litvinova, M., Merler, S., Piontti, A.P., Mu, K., Rossi, L., Sun, K., Viboud, C., Xiong, X., Yu, H., Halloran, M.E., Longini Jr. I.M. and Vespignani, A. (2020). The effect of travel restrictions on the spread of the 2019 novel coronavirus (COVID-19) outbreak. Science, 368 (6489): 395-400. DOI: 10.1126/science.aba9757

Chirico, F., Nucera, G., \& Magnavita, N. (2020). Protecting the mental health of healthcare workers during the COVID-19 emergency. BJPsych International, 1-2.

Choudhury, T., Debski, M., Wiper, A., Abdelrahman, A., Wild, S., Chalil, S., ... \& Abdelaziz, H. K. (2020). COVID-19 pandemic: looking after the mental health of our healthcare workers. Journal of occupational and environmental medicine, 62(7), e373-e376.

Çırakoğlu, O. C. (2011). Domuz Gribi (H1N1) Salgınıyla İlişkili Algıların, Kaygı ve Kaçınma Düzeyi Değişkenleri Bağlamında İncelenmesi. Türk Psikoloji Dergisi, 26(67).

Dai, Y., Hu, G., Xiong, H., Qiu, H., \& Yuan, X. (2020). Psychological impact of the coronavirus disease 2019 (COVID-19) outbreak on healthcare workers in China. MedRxiv.

Di Tella, M., Romeo, A., Benfante, A., \& Castelli, L. (2020). Mental health of healthcare workers during the COVID-19 pandemic in Italy. Journal of evaluation in clinical practice, 26(6), 1583-1587.

Enli Tuncay, F., Koyuncu, E., \& Özel, Ş. (2020). Pandemilerde Sağlık Çalışanlarının Psikososyal Sağlığını Etkileyen Koruyucu ve Risk Faktörlerine İlişkin Bir Derleme. ANKARA MEDICAL JOURNAL, 20(2), 488-504.

Gold, J. A. (2020). COVID-19: adverse mental health outcomes for healthcare workers. BMJ; 369, doi: https://doi.org/10.1136/bmj.m1815.

Hall, H. (2020). The effect of the COVID-19 pandemic on healthcare workers' mental health. Journal of the American Academy of PAs, 33(7), 45-48.

Heath, C., Sommerfield, A., \& von Ungern-Sternberg, B. S. (2020). Resilience strategies to manage psychological distress among healthcare workers during the COVID-19 pandemic: a narrative review. Anaesthesia, 75(10), 1364-1371.

Herzlich, C. (1973). Health and illness: A social psychological analysis.(Çev. D. Graham).

Herzlich, C., \& Pierret, J. (1989). The construction of a social phenomenon: AIDS in the French press. Social Science \& Medicine, 29(11), 1235-1242.

Huang, C., Wang, Y., Li, X., Ren, L., Zhao, J., Hu, Y., ... \& Cheng, Z. (2020). Clinical features of patients infected with 2019 novel coronavirus in Wuhan, China. The lancet, 395(10223), 497-506.

Ogolodom, M. P., Mbaba, A. N., Alazigha, N., Erondu, O. F., Egbe, N. O., Golden, I., ... \& Eke, C. M. (2020). Knowledge, attitudes and fears of healthCare workers towards the corona virus disease (COVID-19) pandemic in South-South, Nigeria. Health Sci J.

Pala, S. Ç., \& Metintas, S. (2020). Covıd-19 Pandemisinde Sağlık Çalışanları. Estüdam Halk Sağlı̆̆ı Dergisi, 5 , 175-187.

Polat, Ö. P., \& Coşkun, F. (2020). COVID-19 Salgınında sağlık çalışanlarının kişisel koruyucu ekipman kullanımları ile depresyon, anksiyete, stres düzeyleri arasındaki ilişkinin belirlenmesi. Batı Karadeniz Tip Dergisi, 4(2), 51-58.

Que, J., Le Shi, J. D., Liu, J., Zhang, L., Wu, S., Gong, Y., ... \& Ran, M. (2020). Psychological impact of the COVID-19 pandemic on healthcare workers: a cross-sectional study in China. General psychiatry, 33(3).

Saatçi, E. (2020). COVID-19 Pandemisi ve sağlık çalışanları: Yaşatmak mı yaşamak mı?. Türkiye Aile Hekimliği Dergisi, 24(3), 153-166.

Sakaoğlu, H. H., Orbatu, D., Emiroglu, M., \& Çakır, Ö. (2020). Covid-19 Salgını Sırasında Sağlık Çalışanlarında Spielberger Durumluk ve Sürekli Kaygı Düzeyi: Tepecik Hastanesi Örneği. Tepecik Eğit. Ve Araşt. Hast. Dergisi, 30, 1-9.

Shaukat, N., Ali, D. M., \& Razzak, J. (2020). Physical and mental health impacts of COVID-19 on healthcare workers: a scoping review. International Journal of Emergency Medicine, 13(1), 1-8. 
Shechter, A., Diaz, F., Moise, N., Anstey, D. E., Ye, S., Agarwal, S., \& Claassen, J. (2020). Psychological distress, coping behaviors, and preferences for support among New York healthcare workers during the COVID-19 pandemic. General hospital psychiatry, 66, 1-8.

Spoorthy, M. S., Pratapa, S. K., \& Mahant, S. (2020). Mental health problems faced by healthcare workers due to the COVID-19 pandemic-A review. Asian journal of psychiatry, 51, 102119.

Strielkowski, W. (2020). International Tourism and COVID-19: Recovery Strategies for Tourism Organisations.

Taylor, S., Landry, C. A., Rachor, G. S., Paluszek, M. M., \& Asmundson, G. J. (2020). Fear and avoidance of healthcare workers: An important, under-recognized form of stigmatization during the COVID-19 pandemic. Journal of Anxiety Disorders, 75, 102289.

Wang, H., Liu, Y., Hu, K., Zhang, M., Du, M., Huang, H., \& Yue, X. (2020). Healthcare workers' stress when caring for COVID-19 patients: An altruistic perspective. Nursing ethics, 27(7), 1490-1500.

Wilder-Smith, A. (2006). Tourism and SARS. In Tourism in Turbulent Times (pp. 77-86). Routledge.

Yücesan, B., \& Özkan, Ö. (2020). Covıd 19 Pandemi Sürecinin Sağlık Yönetimi Açısından Değerlendirilmesi. Avrasya Să̆lık Bilimleri Dergisi, 3, 134-139.

Yürük Bal, E., \& Çelik, H. (2020). COVID-19 Salgını ile Mücadelede Hemşirenin Rolü. Turkiye Klinikleri Hemsirelik Bilimleri, 12(2). 